\title{
Distribution of blue stain in untreated and DMDHEU treated Scots pine sapwood panels after six years of outdoor weathering
}

\author{
Stergios Adamopoulos • Yanjun Xie · Holger Militz
}

Received: 9 November 2009 / Published online: 29 July 2010

(C) Springer-Verlag 2010

\begin{abstract}
Surface coating and bulk treatment of wood are two effective measures which can, individually or conjointly, protect exterior wood from deterioration. This paper reports on the blue stain attack in coated wood, untreated and modified with DMDHEU, after six years of natural exposure.
\end{abstract}

\section{Introduction}

Wood for exterior uses is normally protected from abiotic and biotic impacts by application of coating systems. Failure of coatings with time causes photodegradation of the underlying wooden substrate, entry of moisture and liquid water and consequently growth of microorganisms.

The performance of coatings on wood can be improved by chemical treatment of the wood substrate to minimize specific problems such as moisture absorption, swelling and shrinkage, susceptibility to photodegradation and microbial attack (Beckers et al. 1998; Xie et al. 2006).

In a previous publication (Xie et al. 2008), treatment with 1,3-dimethylol-4,5-dihydroxyethyleneurea (DMDHEU) resulted in reduced crack formation and less fungal growth in coated Scots pine sapwood panels exposed to weathering for 18 months. The objective of this study was to further investigate how blue stain progresses in coated wood,

S. Adamopoulos $\cdot$ Y. Xie $\cdot$ H. Militz (凶)

Wood Biology and Wood Products, Georg-August-University

Goettingen, Buesgenweg 4, 37077 Goettingen, Germany

e-mail: hmilitz@gwdg.de

\section{S. Adamopoulos}

Department of Forestry and Management of Natural Environment, Technological Educational Institute of Larissa, 43100 Karditsa, Greece both untreated and treated with DMDHEU, after six years of weathering.

\section{Materials and methods}

The material used in this study was flat sawn Scots pine ( $P i$ nus sylvestris L.) sapwood panels of $250 \times 70 \times 15 \mathrm{~mm}^{3}$ $(\mathrm{L} \times \mathrm{T} \times \mathrm{R})$. These panels were modified with DMDHEU or methylated DMDHEU (mDMDHEU) to a weight percent gain of ca. $25 \%$. The untreated and the modified panels were then coated with several colours of water-borne acrylic top coatings obtained from Glasurit GmbH, Münster, Germany. Two of them were paints and three were translucent stains. The paints or stains exhibited main differences in colour and solid concentration (Table 1). In order to accelerate the weathering testing, only one thin layer of coating was used for each panel. Four panels per treatment and coating system were exposed. Details on modification, coating and weathering can be found in a previous report (Xie et al. 2008).

After six years of weathering, the cracking on the weathered surfaces of the panels was evaluated according to DIN EN ISO 4628-4-2007 (2007). The evaluation scale ranges from 0 (no cracks) to 5 (dense pattern of cracks).

Visual assessment of the distribution of blue stain was firstly done after crosscutting the panels in various positions lengthwise. To observe the penetration of fungal hyphae, radial sections were prepared with a sliding microtome along large cracks (minimum $1 \mathrm{~mm}$ wide), small cracks (less than $1 \mathrm{~mm}$ wide) and intact parts on the surfaces. The sections were stained with safranin, mounted on slides and then viewed under a light microscope (Nikon eclipse e600) equipped with a Nikon digital camera (DXM 1200, Nikon Instruments Inc. NY, USA). The presence of blue stain hyphae was noted for the upper part $(0-3.5 \mathrm{~mm})$, middle part 
Table 1 Characteristics of coating types for topcoat application

Tab. 1 Kenndaten von Beschichtungssystemen der Deckschicht
Fig. 1 Appearance of the front surfaces of panels after six years of outdoor weathering: untreated and coated panel with PB (a), DMDHEU treated and coated panel with SB-3 (b), and mDMDHEU treated and coated panel with PW (c)

Abb. 1 Erscheinungsbild der Vorderseite von Prüfkörpern nach einer 6-monatigen Außenbewitterung:

(a) Unbehandelte und beschichtete Prüfkörper mit PB, (b) DMDHEU behandelte und beschichtete Prüfkörper mit SB-3 und (c) mDMDHEU behandelte und beschichtete Prüfkörper mit PW

\begin{tabular}{lllllllc}
\hline Code & Type & Colour & Solvent & Binder & $\begin{array}{l}\text { Solid } \\
\text { concentration }(\%)\end{array}$ & $\begin{array}{l}\text { Wet amount } \\
\left(\mathrm{g} / \mathrm{m}^{2}\right)\end{array}$ & $\begin{array}{l}\text { Film dry } \\
\text { thickness }(\mu \mathrm{m})\end{array}$ \\
\hline PB & Paint & Blue & Water & Acrylic & 40.83 & 287 & 53 \\
PW & Paint & White & Water & Acrylic & 62.49 & 752 & 112 \\
SB-1 & Stain & Black & Water & Acrylic & 29.08 & 153 & 28 \\
SB-2 & Stain & Brown & Water & Acrylic & 44.41 & 361 & 41 \\
SB-3 & Stain & Black & Water & Acrylic & 35.73 & 213 & 32 \\
\hline
\end{tabular}

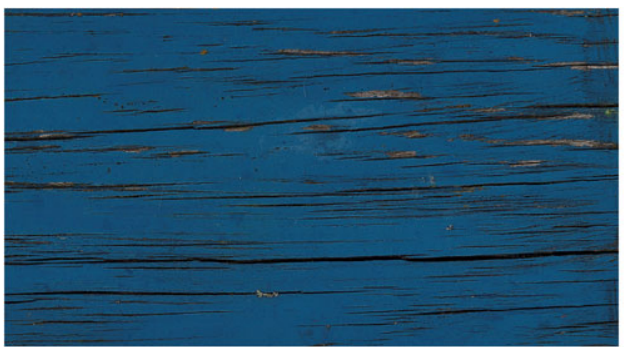

a

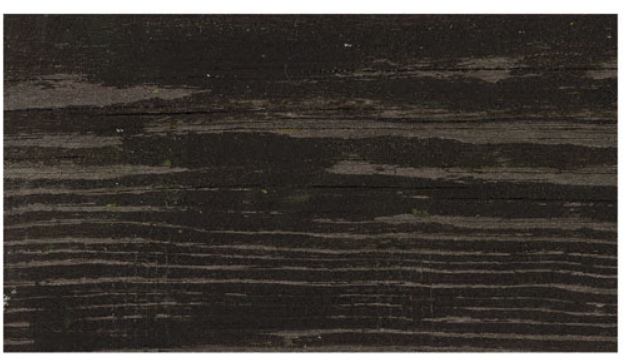

b

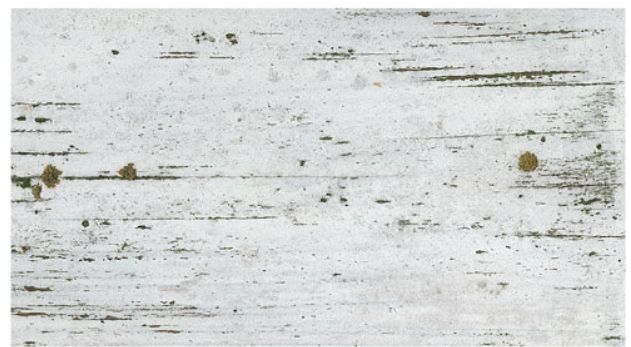

c
$(3.5-10.5 \mathrm{~mm})$ and lower part $(10.5-15 \mathrm{~mm})$ of the radial sections, moving from the front to the reverse surfaces of the panels.

\section{Results}

Weathering of coated panels over a six year period caused extensive surface cracking and discoloration due to fungal colonization which was more severe in the case of untreated panels (Fig. 1a, b and c).

Six-year weathering resulted in a failure of the coating film on the untreated sample surfaces, mostly flaking and peeling for acrylic stains but cracking for acrylic paints. The very thin layers of stain coatings were mostly gone; however, the somewhat thicker white and blue paint coatings remained on the surfaces at a higher degree. The coating films on the treated panels displayed a comparable degradation to the one on the untreated controls. After 18 months of weathering, an improved effect of the coating performance due to wood substrate modification was observed (Xie et al. 2008). After six years, such improvement is likely to become obscure due to the thin layer of coatings applied and the fail- ure of coating itself after suffering from a long term surface photodegradation/leaching. The modified wood substrates, however, showed fewer cracks $(\mathrm{CR}=3$ or 4 in one case, Table 2) with all coating types compared to the untreated panels $(\mathrm{CR}=5)$. This can be attributed to a lower water uptake and moisture sorption and to the higher dimensional stability of the substrate.

The severe cracking of untreated panels enabled fungal spores to reach the wood substrate, germinate and spread widely due to moisture accumulation (Fig. 2a). The fungi started to grow from the front surface of the panels and reached the reverse through the ray cells. Blue stain hyphae were observed in every part (upper, middle, lower) of radial sections taken along both large and small cracks (Table 2). Slightly less blue stain fungi was noted only in the case of blue acrylic paint coating (PB).

In DMDHEU treated panels, the crosscut surfaces showed considerably less stained area which was restricted only close to the wood and coating interface. Microscopic examination of radial sections along small cracks revealed that the infection was restricted to the upper parts of the panels with hyphae not being able to penetrate further and reach the interior parts (Table 2, Fig. 2b and d). Sectioning along in- 
Table 2 Crack ranking and distribution of blue stain in the panels as observed microscopically

Tab. 2 Klassifizierung von Rissen sowie Verteilung von Bläue in den Prüfkörpern nach mikroskopischer Auswertung

\begin{tabular}{lllll}
\hline Sample & Crack ranking & \multicolumn{2}{l}{ Distribution of blue stain } & \\
\cline { 4 - 5 } & & Along large cracks & Along small cracks & Along intact parts \\
\hline Untreated and uncoated & 5 & $\mathrm{U}, \mathrm{M}, \mathrm{L}$ & $\mathrm{U}, \mathrm{M}, \mathrm{L}$ & $\mathrm{na}$ \\
Untreated and coated with PB & 5 & $\mathrm{U}, \mathrm{M}, \mathrm{L}$ & $\mathrm{U}, \mathrm{U}, \mathrm{M}, \mathrm{L}$ & $\mathrm{na}$ \\
Untreated and coated with SB-2 & 5 & $\mathrm{U}, \mathrm{M}, \mathrm{L}$ & $\mathrm{U}, \mathrm{M}, \mathrm{L}$ & $\mathrm{U}$ \\
Untreated and coated with SB-1 & 5 & $\mathrm{U}, \mathrm{M}, \mathrm{L}$ & $\mathrm{U}$ & - \\
DMDHEU treated and coated with PW & 3 & na & $\mathrm{U}, \mathrm{M}$ & - \\
DMDHEU treated and coated with PB & 3 & na & $\mathrm{U}$ & - \\
DMDHEU treated and coated with SB-2 & 4 & $\mathrm{U}, \mathrm{M}, \mathrm{L}$ & $\mathrm{U}$ & - \\
DMDHEU treated and coated with SB-3 & 3 & na & na & U \\
mDMDHEU treated and coated with PW & 3 & na & & - \\
mDMDHEU treated and coated with PB & 3 & &
\end{tabular}

U: upper part (0-3.5 mm), M: middle part (3.5-10.5 mm), L: lower part (10.5-15 mm)

na: not applicable

-: no evidence of blue stain

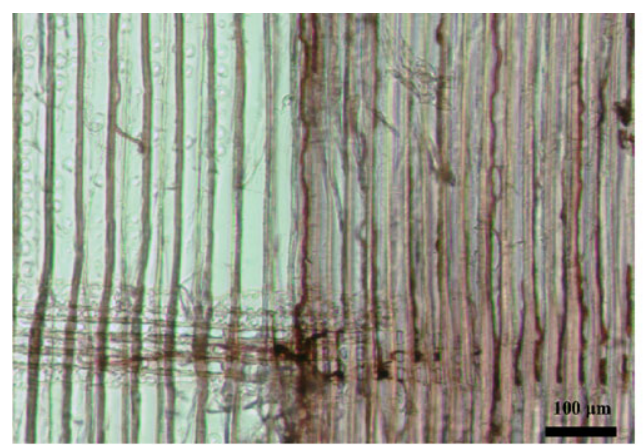

a

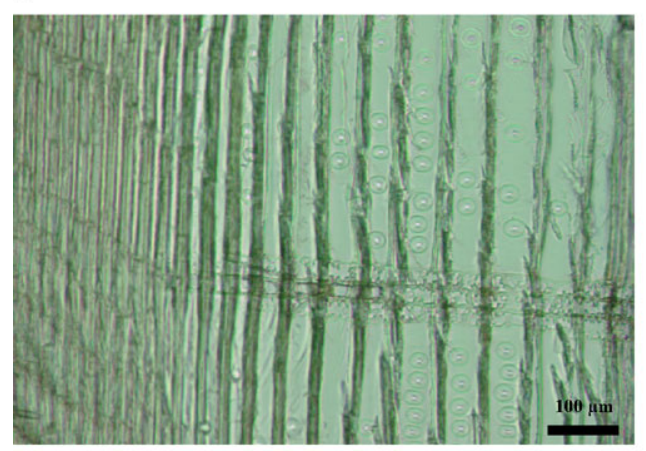

c

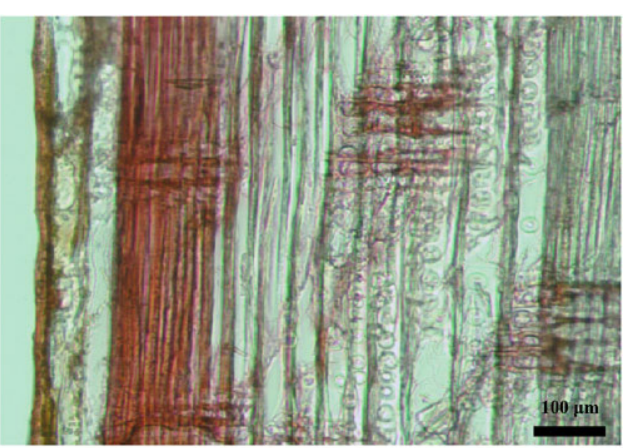

b

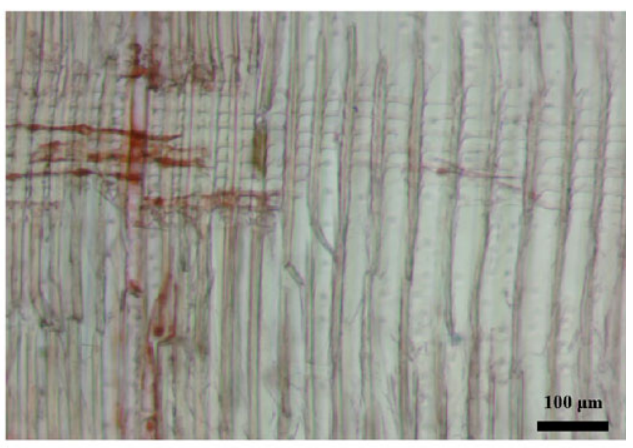

d

Fig. 2 Micrographs of radial sections: middle part of untreated panel and coated with SB-1 (a), upper part of DMDHEU treated panel and coated with SB-2 (b), upper part of DMDHEU treated panel and coated with SB-3 (c), and upper part of mDMDHEU treated panel and coated with PW (d). Note: sections (a), (b) and (d) were taken along small cracks and section (c) along intact part. Every micrograph, from the left to the right, it was moved from the front surface to the inner part of the wood samples

Abb. 2 Mikroskopische Aufnahmen in radialer Richtung: (a) Mittlere Schicht von unbehandelten und mit SB-1 beschichteten Prüfkörpern, (b) obere Schicht von DMDHEU behandelten und mit SB-2 beschichteten Prüfkörpern, (c) obere Schicht von DMDHEU behandelten und mit SB-3 beschichteten Prüfkörpern sowie (d) obere Schicht von mDMDHEU behandelten mit PW beschichteten Prüfkörpern. Anmerkung: die Schichten in (a), (b) und (d) wurden entlang von kleinen Rissen entnommen, die Schicht (c) aus einem unbeschädigten Teil des Prüfkörpers. Die mikroskopischen Aufnahmen zeigen jeweils links die äußere Schicht des Prüfkörpers und rechts dessen mittlere Schicht 
tact parts showed no evidence of blue stain (Table 2, Fig. 2c) suggesting that coating prohibited fungal growth. The extent of fungal penetration was higher for the brown stain coating SB-2 due to a higher crack ranking $(\mathrm{CR}=4)$. The lowest degree of blue stain colonisation in DMDHEU treated panels can be explained by changes in the properties of wood, e.g. reduced water uptake and increased dimensional stability (Xie et al. 2008).

The overall results suggest that it is difficult to examine any improvement in coating performance by wood substrate treatment with DMDHEU or mDMDHEU due to the failure of the coating film itself after six years of outdoor weathering. However, treatments of wood substrate considerably reduced the growth of blue staining in the wood.

\section{References}

Beckers EPJ, de Meijer M, Militz H (1998) Performance of finishes on wood that is chemically modified by acetylation. J Coat Technol 79(878):59-67

DIN EN ISO 4628-4-2007 (2007) Beschichtungsstoffe-Beurteilung von Beschichtungsschäden-Bewertung der Menge und der Größe von Schäden und der Intensität von gleichmäßigen Veränderungen im Aussehen-Teil 4: Bewertung des Rissgrade. DINTaschenbuch 400, Bewitterung, Beuth

Xie Y, Krause A, Militz H, Mai C (2006) Coating performance of finishes on wood modified with an N-methylol compound. Prog Org Coat 57:291-300

Xie Y, Krause A, Militz H, Mai C (2008) Weathering of uncoated and coated wood treated with methylated 1,3-dimethylol4,5-dihydroxyethyleneurea(mDMDHEU). Holz Roh- Werkst 66(6):455-464 